\title{
PENGEMBANGAN PERTANIAN ORGANIK MELALUI BUDIDAYA TANAMAN PALAWIJA DENGAN APLIKASI TEKNOLOGI RIZOBAKTERI INDIGENOS DI NAGARI SUNGAI DURIAN KABUPATEN SOLOK
}

\section{ORGANIC AGRICULTURAL DEVELOPMENT THROUGH CULTIVATION OF SECONDARY CROPS WITH THE APPLICATION OF INDIGENOUS RHIZOBACTERIA TECHNOLOGY IN NAGARI SUNGAI DURIAN OF SOLOK DISTRICT}

\author{
Yulmira Yanti $^{1^{*}}$, Munzir Busniah ${ }^{1}$, Trimurti Habazar ${ }^{1}$, Zulfadli Syarief ${ }^{2}$, \\ Intan Sari Pasaribu ${ }^{3}$
}

${ }^{1)}$ Dosen Program Studi Proteksi Tanaman Fakultas Pertanian Universitas Andalas Padang 25163

${ }^{2)}$ Dosen Program Studi Agroekoteknologi Fakultas Pertanian Universitas Andalas Padang 25163

${ }^{3)}$ Mahasiswa Program Studi Agroteknologi Fakultas Pertanian Universitas Andalas Padang 25163

*Email: yy.anthie79@gmail.com, mira23@gr.unand.ac.id

\begin{abstract}
ABSTRAK
Nagari Sungai Durian Kabupaten Solok merupakan salah satu nagari yang memiliki berbagai permasalahan seperti kekeringan, tingginya jumlah lahan tidur dan jauhnya akses. Tanaman utama yang ditanam saat musim hujan adalah padi sawah, namun sebagian besar lahan menjadi lahan tidur saat musim kemarau. Solusi yang dapat ditawarkan adalah dengan penanaman tanaman palawija yang lebih tahan terhadap kekeringan dan penggunaan rizobakteri sebagai agens pengendali hama dan penyakit. Selain sebagai agens pengendali hama dan penyakit, penggunaan rizobakteri juga sebagai PGPR (Plant Growth Promoting Rhizobacteria) yang mampu meningkatkan pertumbuhan dan hasil tanaman. Tujuan dari program pengabdian masyarakat ini adalah memberikan pengetahuan kepada masyarakat dalam budidaya tanaman palawija dengan aplikasi teknologi rizobakteri indigenos. Kegiatan ini dilakukan dengan cara sosialisasi dan demonstrasi plot. Adapun luaran yang didapat dari program pengabdian masyarakat ini adalah :1) Masyarakat mendapatkan pengetahuan serta menguasai teknik budidaya tanaman palawija yang baik (jagung, singkong dan ubi jalar); 2) pengetahuan mengenai teknologi pemanfaatan rizobakteri sebagai agens hayati dalam pengendalian hama dan penyakit tanaman serta peningkatan pertumbuhan dan hasil tanaman palawija; 3) Mendapatkan produk pertanian organik (jagung, singkong dan ubi jalar) yang bebas dari penggunaan pupuk dan pestisida sintetik.
\end{abstract}

Kata kunci : Agens hayati, Rizobakteri, PGPR, Tanaman palawija

\begin{abstract}
Nagari Sungai Durian of Solok District is one of the village that has various problems such as drought, high number of unused land and the distance of urban access. The main crops in this village grown during the rainy season are wetland paddy, but most of the land becomes unused during the dry season. The solution that can be offered is by planting crops that are more resistant to drought and the use of rhizobacteria as pest and disease control agents. In addition to pest and disease control agents, the use of rhizobacteria which also called PGPR (Plant Growth Promoting Rhizobacteria) that can increase growth and yield of plants. The purpose of this community service program is to provide knowledge to the community in the cultivation of secondary crops with the application of indigenous rhizobacteria technology. This activity is done by socialization and demonstration plot. The outcomes obtained from this community service program are: 1) Communities gain knowledge and master good cultivation of secondary crops (corn, cassava and sweet potatoes); 2) knowledge of rhizobacteria utilization technology as biological agent in plant pests and diseases control and improvement of crops' growth and yield; 3) Obtain organic agricultural products (corn, cassava and sweet potato) that are free from the use of synthetic fertilizers and pesticides.
\end{abstract}

Keywords: Biological agents, Rhizobacteria, PGPR, Secondary crops 


\section{PENDAHULUAN}

Kabupaten Solok Merupakan salah satu dari 19 kabupaten/ kota di Propinsi Sumatera Barat, dengan luas $3.738 \mathrm{Km} 2$. Kabupaten Solok merupakan merupakan salah satu kabupaten yang memiliki lokasi wilayah yang strategis di Propinsi Sumatera Barat, yaitu berada pada jalur lintas regional. Secara geografis Kab. Solok memiliki Letak Geografis antara $00^{\circ} 32^{\prime \prime}$ 14" - 01 46" 45" LS dan $100^{\circ} 25^{\circ} 00^{\prime \prime}$ 101 41" 41"BT (Profil Kab solok. 2012). Sebagian besar penduduk Kab Solok bergantung pada sektor pertanian tanaman holtikultura, pangan dan perikanan. Sementara sumber daya potensial lainnya pertambangan, perkebunan dan pariwisata (Bapeda Kab Solok, 2013).

Sebagai kabupaten agraris struktur ekonomi Kabupaten Solok masih didominasi sektor pertanian dengan sub sektor terdiri dari tanaman pangan dan hortikultura, tanaman perkebunan, Peran sektor pertanian sejak Tahun 2006 hingga Tahun 2011 memperlihatkan trend meningkat. Pembangunan pertanian merupakan sektor utama yang memberikan kontribusi yang besar terhadap pembangunan daerah. Potensi sumberdaya lahan pertanian terbesar adalah lahan holtikultura dengan luas lahan yaitu $\pm .48,537$ ha, lahan untuk pengembangan tanaman sawah luas lahannya mencapai \pm .7 .047 ha (Bappeda Kabupetan Solok
2012).

Kabupaten Solok merupakan salah satu sentra produksi tanaman pangan dan hortikultura di Sumatera Barat, namun produksi hanya terpusat pada beberapa kecamatan seperti kecamatan Lembah Gumanti, Danau Kembar dan lain-lain, sedangkan beberapa kecamatan seperti Kecamatan IX Koto Sungai Lasi memiliki keterbatasan dalam produksi tanaman. Hal tersebut disebabkan oleh posisi geografis yang kurang sesuai karena wilayah kecamatan tersebut didominasi oleh jarak yang jauh dari pusat kota, akses yang kurang memadai, perbukitan yang terjal, serta ketersediaan air yang terbatas. Hal tersebut menyebabkan lokasi tersebut kurang memungkinkan sebagai sentra produksi tanaman hortikultura dan padi sawah.

Nagari Sungai Durian merupakan salah satu Nagari yang berada di Kecamatan IX Koto Sungai Lasi. Nagari ini berjarak 30 km dari Pusat Kota Solok. Selain jarak yang cukup jauh, akses yang dilalui untuk dapat ke Nagari ini juga cukup sulit karena letak Nagari Sungai Durian yang berada pada daerah perbukitan. Nagari ini juga mengalami kesulitan akses air karena letak geografis nagari (PU,2014), sehingga lahanlahan potensial di Nagari ini tidak cocok dikembangkan sebagai sentra produksi hortikultura dan padi sawah. Hal ini menyebabkan banyaknya lahan tidur 
didaerah tersebut. Salah satu alternatif yang dapat dilakukan adalah dengan penanaman tanaman palawija.

Palawija merupakan kelompok komoditas tanaman pangan kedua terpenting setelah padi. Jagung, kedelai, dan kacang tanah merupakan komoditas palawija utama yang diusahakan petani pada musim kemarau pada berbagai jenis pengairan di lahan sawah (Rusastra et al., 2004). Tanaman palawija mampu menghemat air di musim kering sehingga cocok ditanam pada saat musim kemarau ataupun pada daerah yang memiliki kesulitan air. Pengembangan tanaman palawija di Nagari ini juga akan turut mendukung program pemerintah dalam menggalakkan diversifikasi pangan di Indonesia demi mempertahankan ketahanan pangan sesuai dengan Peraturan Pemerintah No. 68 tahun 2002 tentang ketahanan Pangan dan Peraturan Presiden No. 22 tahun 2009 tentang Percepatan Penganekaragaman Konsumsi Pangan. Dalam budidaya palawija kendala yang muncul adalah serangan hama dan penyakit tanaman, serta kurangnya produktivitas dikarenakan lahan kurang subur. Untuk mengatasi masalah tersebut, teknik yang digunakan adalah aplikasi rizobakteri indigenos.

Teknologi yang sedang pesat perkembangannya saat ini adalah pemanfaatan mikroorganisme (bakteri saprofit non patogenik) yang dieksplorasi dari rizosfer tanaman (rizobakteri) yang dapat memacu pertumbuhan tanaman (Loon, 2007). Lebih lanjut dijelaskan bahwa rizobakteri memiliki kemampuan mengolonisasi rizosfer secara agresif dan beberapa jenis rizobakteri mampu berperan ganda sebagai biofertilizer dan bioprotektan pada tanaman (Ashrafuzzaman et al., 2009).

Rizobakteri indigenos berpotensi sebagai agens hayati sekaligus pemicu pertumbuhan tanaman. Mikroorganisme yang sudah banyak dilaporkan mampu sebagai agen biokontrol adalah kelompok Plant Growth Promoting Rizobakteria (PGPR). PGPR merupakan kelompok bakteri heterogen yang ditemukan dalam kompleks rhizosfer, permukaan akar dan berasosiasi dalam akar, serta dapat meningkatkan kualitas pertumbuhan tanaman secara langsung ataupun tidak langsung (Joseph et al., 2007). PGPR pada perakaran tanaman dapat dikelompokkan berdasarkan tempat kolonisasinya, yaitu berada dalam komplek rizosfer, di permukaan akar (rizoplan) dan di dalam jaringan akar (endofit) (Soesanto, 2008).

Rizobakteri mempunyai kemampuan dalam menginduksi ketahanan tanaman dan terlihat kecenderungan isolat yang efektif mengendalikan penyakit tanaman adalah yang berasal dari perakaran tanaman yang bersangkutan (indigenos) (Yanti et al., 2013). Bakteri indigenos lebih baik 
diintroduksikan pada tanaman, sebab bakteri indigenos lebih dapat beradaptasi pada lingkungan dan lebih kompetitif dibanding bakteri non-indigenos (Bhattarai dan Hess, 1993).

Adapun tujuan dari program pengabdian masyarakat ini adalah memberikan pengetahuan kepada masyarakat dalam budidaya tanaman palawija dengan aplikasi teknologi rizobakteri indigenos. Dengan adanya kegiatan ini diharapkan masyarakat mengurangi penggunaan pupuk dan pestisida sintetik.

\section{METODE PELAKSANAAN}

Program pengabdian masyarakat ini diadakan pada bulan juli - agustus 2017 dengan lokasi kegiatan di Nagari Sungai Durian, Kecamatan Sungai Lasi, Kabupaten Solok, Sumatera Barat (Gambar 1). Peserta kegiatan ini ialah mahasiswa KKN 2017 dan masyarakat Nagari Sungai Durian.
Adapun bahan yang diperlukan dalam budidaya palawija dengan aplikasi rizobakteri indigenos adalah benih jagung, bibit ubi kayu, suspensi rizobakteri indigenos, pupuk dan bahan-bahan pendukung lainnya. Sedangkan alatnya adalah cangkul dan parang.

Program pengabdian masyarakat ini dilakukan dengan metode penyuluhan, demonstrasi, dan pendampingan. Kegiatan penyuluhan dilaksanakan dalam bentuk ceramah dan diskusi mengenai : 1) pemanfaatan lahan tidur; 2) budidaya palawija; 3) manfaat dan pembuatan rizobakteri indigenos.

Selanjutnya dilakukan pembuatan demplot tanaman palawija, Pelatihan pembuatan dan aplikasi agens hayati rizobakteri. Demonstrasi dilakukan langsung oleh masyarakat dibantu oleh Mahasiswa KKN 2017 mulai dari penanaman hingga panen.

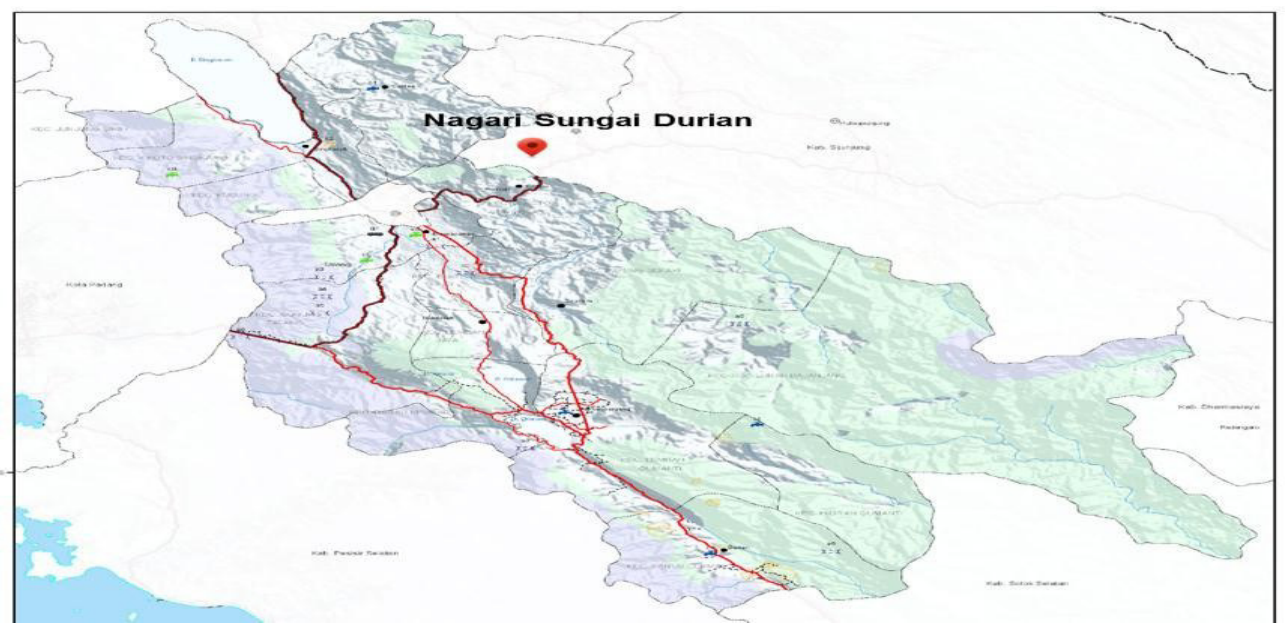

Gambar 1. Peta Kabupaten Solok 


\section{HASIL DAN PEMBAHASAN}

\section{Penyuluhan dan Diskusi}

Penyuluhan dilakukan di gedung balai serba guna Nagari Sungai Durian dengan melibatkan aparat pemerintahan Nagari dan masyarakat setempat (gambar 2). Adapun materi yang diberikan ialah: 1) pemanfaatan lahan tidur; 2) budidaya palawija; 3) manfaat dan pembuatan rizobakteri indigenos. Hasil yang diperoleh setelah melakukan penyuluhan mengenai budidaya

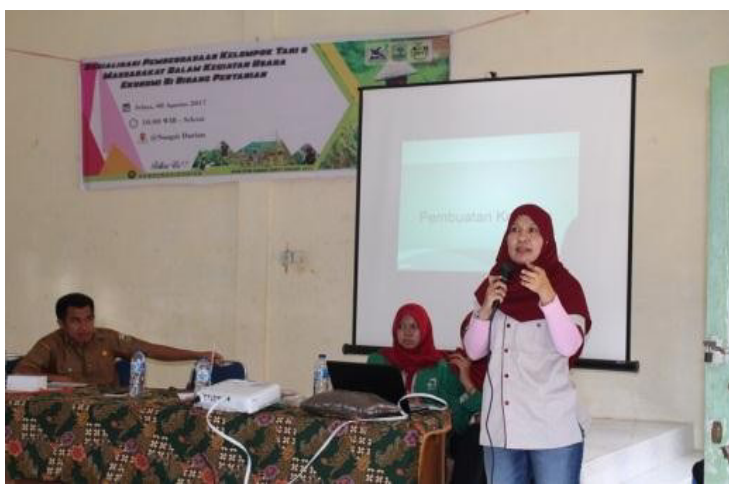

tanaman palawija dengan aplikasi rizobakteri indigenos masyarakat memahami budidaya tanaman palawija yang baik, mengurangi penggunaan pupuk dan pestisida sintetis dan diganti dengan aplikasi rizobakteri indigenos.Maka dari itu lingkungan dan keseimbangan ekosistem di daerah sungai durian menjadi terjaga. Tidak hanya itu, kesehatan dari petani dan masyarakat juga terlindungi

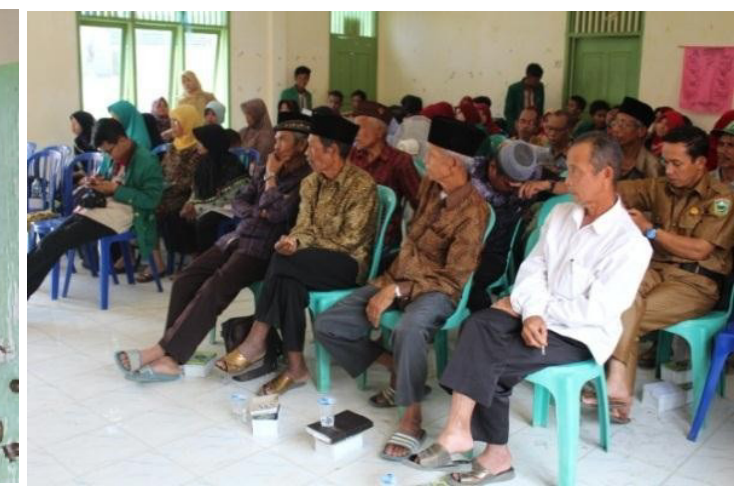

Gambar 2. Penyampaian Materi dan diskusi

\section{Kegiatan Budidaya Tanaman Palawija}

Pada kegiatan ini masyarakat bersama mahasiswa KKN 2017 didampingi tim melakukan budidaya tanaman palawija mulai penanaman hingga panen. Adapun rangkaian kegiatannya adalah sebagai berikut :

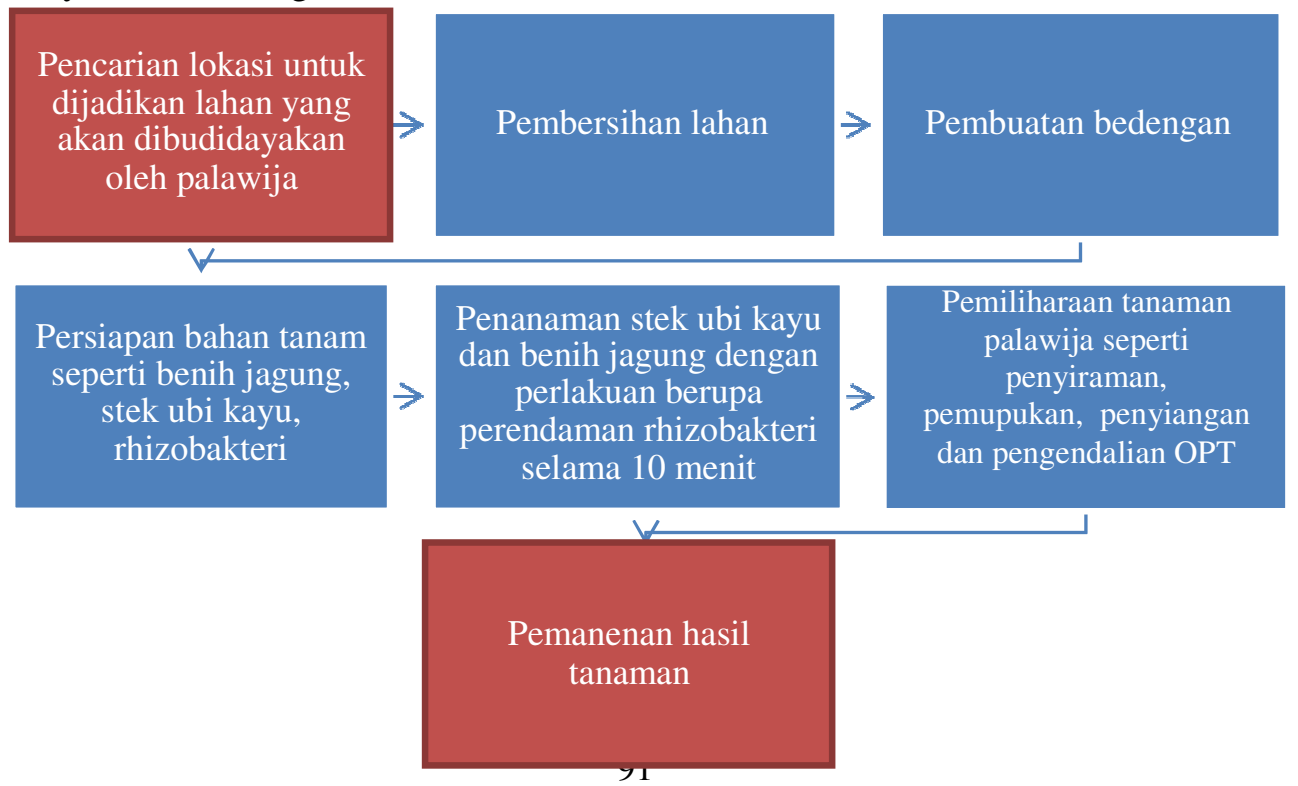


Budidaya tanaman palawija dilakukan pada tanggal 20 Mei 2017. Penanaman dilakukan di salah satu lahan tidur yang ada di Nagari Sungai Durian. Tanaman yang dibudidayakan adalah jagung dan ubi kayu. Tanaman tersebut dapat tumbuh dengan baik dan subur di nagari Sungai Durian, terlebih setelah diberikan perlakukan dengan melakukan perendaman

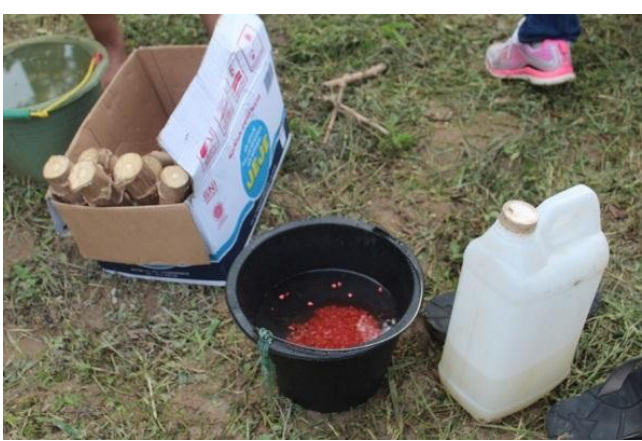

(a) menggunakan rhizobakteri (gambar 3). Pemberian rhizobakteri sebelum dilakukan penanaman dapat meningkatkan kualitas bibit. Cara ini juga dimaksudkan agar produksi palawija kedepanya meningkat. Rizobakteri yang diberikan berasal dari Laboratorium Mikrobiologi jurusan Hama Penyakit Tumbuhan Fakultas Pertanian Universitas Andalas (gambar 4).

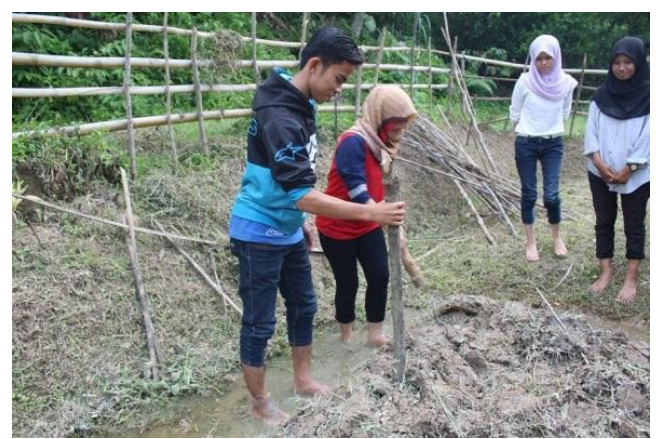

(b)

Gambar 3. Penanaman (a) perendaman benih dan bibit; (b) penanaman benih jagung.

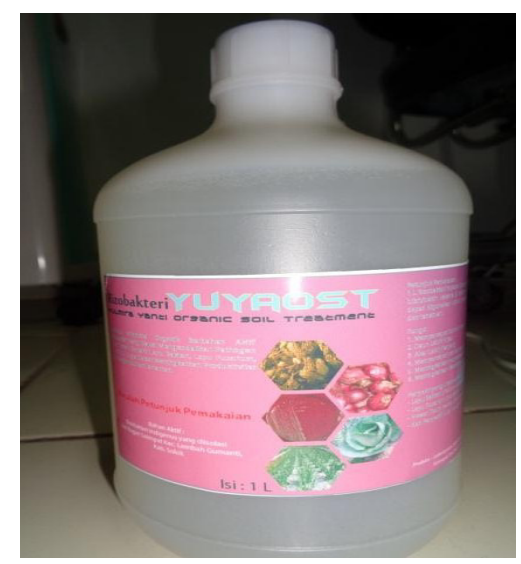

Gambar 4. produk rizobakteria indigenos

Perawatan yang dilakukan dalam budidaya palawija ini adalah pemupukan dan penyiangan gulma (gambar 5). Penyiangan gulma dilakukan 3 hari sekali untuk mengurangi persaingan unsur hara dan mengurangi terjadinya serangan hama dan pathogen penyebab penyakit. Namun serangan hama vertebrata yaitu babi tidak dapat dihindari jika tidak diberi pagar kawat disekeliling lahan. Untuk itu, pada sekeliling lahan di beri pagar berduri untuk menghindari serangan hama babi. 


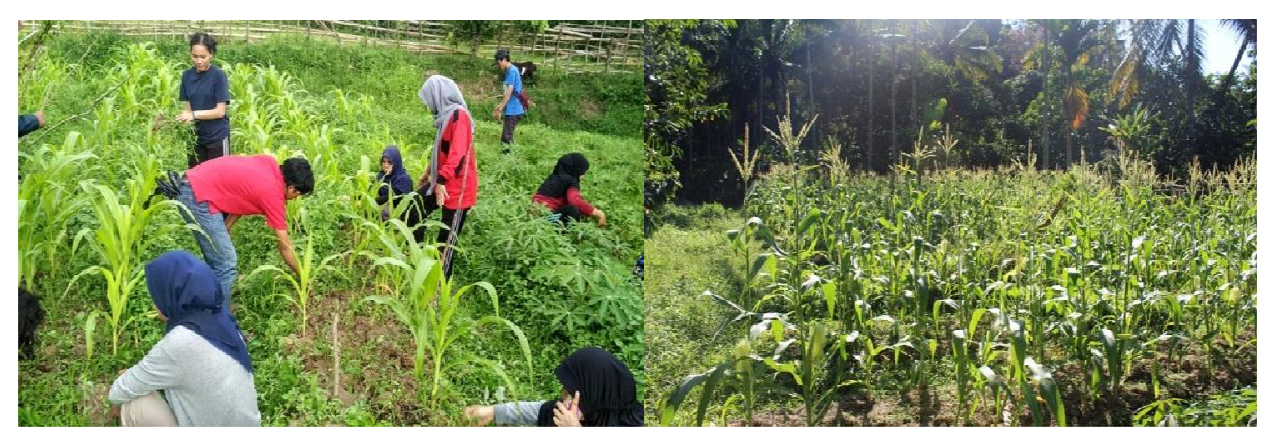

Gambar 5. Perawatan tanaman jagung dan ubi kayu

Rhizobakteri pemacu tumbuh tanaman yang lebih popular disebut Plant Growth Promoting Rhizobacteria (PGPR) merupakan kelompok bakteri menguntungkan yang secara aktif mengkolonisasi rizosfir. PGPR berperan penting dalam meningkatkan pertumbuhan tanaman, hasil panen dan kesuburan lahan (Wahyudi, 2009). Hal tersebut telah terlihat dari hasil panen jagung yang memiliki ukuran lebih besar daripada umumnya. Panen hasil dilakukan oleh masyarakat bersama Mahasiswa KKN (gambar 6).

Hasil panen budidaya palawija dijadikan berbagai produk olahan makanan berbahan utama jagung dan singkong. Sehingga nilai jual dari hasil tanaman menjadi lebih tinggi dan dapat menjadi peluang usaha bagi masyarakat.

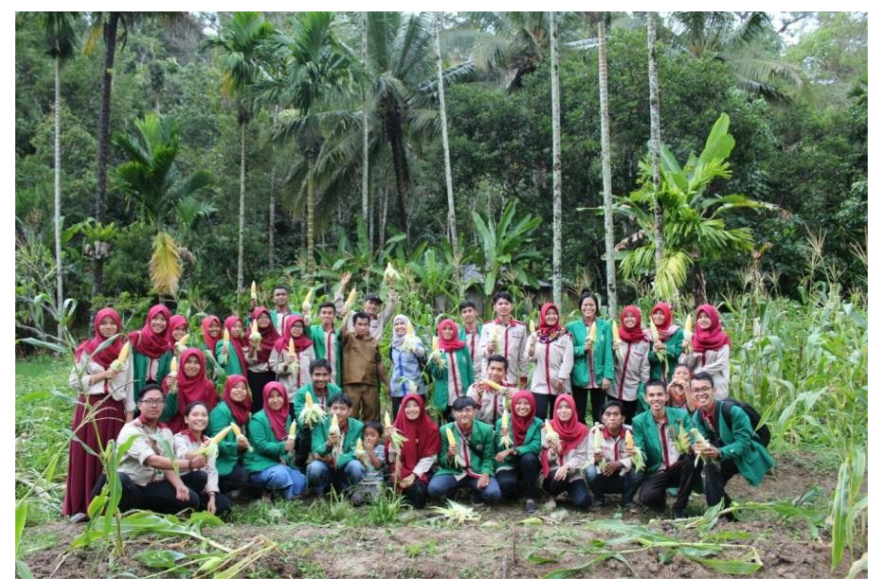

Gambar 6. Foto bersama setelah panen

\section{KESIMPULAN}

Kegiatan ini sangat bermanfaat bagi masyarakat khususnya masyarakat Nagari Sungai Durian. Antusias dan partipasi aktif dari masyarakat sangat menunjang keberhasilan dari kegiatan ini. Kegiatan ini telah mampu mengedukasi masyarakat khsusnya petani sekitar tentang budidaya tanaman palawija dengan aplikasi rizobakteri indigenos.

Sedangkan luaran yang didapat adalah :

1. Terciptanya pemahaman masyarakat akan manfaat dari rizobakteria indigenos

2. penurunan tingkat ketergantungan petani 
terhadap pupuk anorganik dan pestisida sintetik.

3. produk berupa rizokompos.

4. masyarakat mampu menghasilkan produk pertanian organik yang bebas pestisida sintetik.

Banyaknya manfaat dari program ini, untuk itu diharapkan agar kegiatan ini bersifat berkelanjutan agar menjadikan produk pertanian organik sebagai bisnis yang menjanjikan bagi masyarakat khususnya masyarakat Nagari Sungai Durian.

\section{UCAPAN TERIMAKASIH}

Penulis mengucapkan terimakasih kepada Kementrian Ristek dan Dikti Republik Indonesia yang telah mendanai program pengabdian masyarakat ini dengan nomor kontrak

012/SP2H/PPM/DRPM/IV/2017 tanggal 30

Maret 2017. Penulis juga mengucapkan terimakasih kepada Universitas Andalas yang telah mendukung berjalannya program ini. Ucapan terimakasih juga penulis sampaikan kepada Wali Nagari, staf pemerintahan dan seluruh masyarakat Nagari Sungai Durian serta Mahasiswa KKN 2017.

\section{DAFTAR PUSTAKA}

1. Ashrafuzzaman M, Hossen FA, Ismail MR, Hoque MA, Islam MZ, Shahidullah SM, \& Meon S. 2009. Efficiency of plant growth- promoting rhizobacteria (PGPR) for the enhancement of rice growth. African J. Biotechnol. 8:12471252.

2. Bappeda Kabupaten Solok. 2013. Laporan Kegiatan Dinas Pemerintah Daerah Kabupaten Solok tahun 2012.
Badan Perencanaan dan Pembangunan Daerah Kabupaten Solok.

3. Bhattarai, T., Hess, D., 1993. Yield responses of Nepalese spring wheat $(T$. aestivum $\mathrm{L}$ ) cultivars to inoculation with Azospirillum spp.. Plant and Soil. 151: 67- 76.

4. Joseph B , Ranjan PR., Lawrence, R., 2007. Characterization of plant growth promoting rhizobacteria associated with chickpea (Cicerarietinum L.). J. Plant Production 1(2):141-151.

5. Profil Kabupaten Solok 2012. Http/www. Google.co.id .(diakses 12 Mei 2016).

6. PU (Kementerian Pekerjaan Umum dan Perumahan Rakyat Republik Indonesia, 2014. Peta Infrastruktur Kabupaten Solok (2014).

http://loketpeta.pu.go.id/peta-

infrastruktur-kabupaten-solok-2014, Diakses 10 Mei 2016.

7. Rusastra, I. W., Rachman, B., \& Friyatno, S., 2004. Analisis daya saing dan struktur proteksi komoditas palawija. Pse.litbang.pertanian.go.id

8. Soesanto, L., 2008. Pengantar Pengendalian Hayati Penyakit Tanaman. Rajawali Pers. Jakarta

9. Van Loon LC. 2007. Plant response to plant growthpromoting rhizobacteria. Eur. J.Plant Pathol 119:243-254.

10.Yanti, Y., Busniah. M., Syarif, A., 2014. IbM Pengelolaan Hama Dan Penyakit Tanaman Berbahan Baku Lokal Di Nagari Salimpat Untuk Meningkatkan Produksi Sayuran Serta Pendapatan Petani. Laporan Pengabdian Kepada masyarakat Iptek Bagi Masyarakat 2014.

11.Yanti,Y, Habazar T, Resti Z, Suhailita D., 2013. Penapisan Isolat Rizobakteri Dari Perakaran Tanaman Kedelai Yang Sehat Untuk Pengendalian Penyakit Pustul Bakteri (Xanthomonas axonopodis Pv. Glycines). Jurnal HPT Tropika Vol.13 (1):24-34.

12.Yanti, Y. Mayerni, R., Yusniwati, 2015. IbM Pemanfaatan Mikroorganisme Lokal Untuk Mengendalikan Hama dan Penyakit Tanaman Bawang Merah Di Nagari Aie Dingin. Laporan Pengabdian kepada Masyarakat Tahun 2015. 